\title{
CONTINUOUS STABILIZATION OF CHARDONNAY WITH ION-EXCHANGE RESIN: INFLUENCE ON PROTEIN AND PHENOLIC PROFILES OF WINE
}

\author{
Johannes de Bruijn ${ }^{1 *}$, Ana Valdebenito ${ }^{1}$, Cristina Loyola ${ }^{1}$ Ignacio Serra $^{2}$, Fernando Salazar ${ }^{3}$, \\ and Francisco López ${ }^{3}$.
}

\begin{abstract}
Unstable proteins may react with polyphenols, forming haze and precipitation in white wines. Therefore, the adsorption of these wine proteins is an essential step in the production of white wines. The objective of this study was to determine the influence of adsorption of these proteins on the stability, and protein and phenolic composition of a Chardonnay wine. In this work, protein stabilization of Chardonnay wine was done by continuous adsorption using a packed bed with a SP-Trisacryl-M adsorbent (Sigma-Aldrich). A more pronounced breakthrough of proteins and turbidity causing compounds was found after treating 65 bed volumes of wine by the resin. An increased retention of the protein fraction of $20-50 \mathrm{kDa}$ during the first 62 bed volumes of treated wine was related to improved wine stability. The removal of phenolics by Trisacryl was low. Caffeic acid and (-)-epicatechin were the main phenolic compounds that could be detected by high performance liquid chromatography (HPLC). Chardonnay, a low protein content wine, improved its stability after Trisacryl treatment due to the adsorption of the $20-50 \mathrm{kDa}$ protein fraction.
\end{abstract}

Key words: adsorption, Trisacryl, Vitis vinifera, fining, Chile.

\section{INTRODUCTION}

Wine colloids may aggregate and subsequently precipitate to form amorphous sediment during storage or flocculate, causing a suspended, unattractive haze in bottled wine, reducing its commercial value and making it unacceptable for sale. In wine stabilization the addition of adsorbents has been required specifically to remove unstable, macromolecular and colloidal wine fractions and to produce stable, clear wines, regardless of storage conditions. The traditional method of white wine stabilization used in most cellars includes the addition of bentonite and silica gel by discontinuous operation. Although the use of bentonite and silica gel is an effective method to stabilize wine, there are some drawbacks, such as a considerable loss of product and aroma compounds

${ }^{1}$ Universidad de Concepción, Facultad de Ingeniería Agrícola, Av. Vicente Méndez 595, Chillán, Chile.

"Corresponding author (jdebruij@udec.cl).

${ }^{2}$ Universidad de Concepción, Facultad de Agronomía, Av. Vicente Méndez 595, Chillán, Chile.

${ }^{3}$ Universitat Rovira i Virgili, Facultat d'Enologia, Departament d'Enginyeria Química, Avenida Països Catalans 26, 43007, Tarragona, Spain.

Received: 25 January 2008.

Accepted: 12 June 2008. and a negative environmental impact due to the generation of solid residues. Recently, De Bruijn et al. (2008) reported only minor changes of physicochemical properties and sensorial characteristics of stabilized Chardonnay after batch adsorption using Trisacryl. Therefore, the development of a continuous fining process using an alternative adsorbent within a packed column could be promising for white wine stabilization.

Proteins, glycoproteins and polyphenols may cause stability problems in white wines. Protein-polyphenol interactions cause flocculation, turbidity and precipitation. The mechanisms leading to haze formation are complex and depend on molecular structures, where haze-active proteins rich in proline and haze-active polyphenols have at least two binding groups, each of which have at least two hydroxy groups on the aromatic ring (Siebert, 1999).

Waters et al. (1996) were the first to identify proteins that cause haze in wines as pathogenesis-related proteins from the grape berry (Vitis vinifera L.). Chitinase ( $32 \mathrm{kDa}$ ) and thaumatin-like protein $(24 \mathrm{kDa})$ are the predominant proteins in free-run juices from grapes and have been identified as the major proteins present in white wines (Waters et al., 1996; Tattersall et al., 1997). These are rich in acidic amino acids such as asparagine and aspartic acid, and aliphatic amino acids such as glycine, threonine 
and serine (Waters et al., 1991). The haze active proteins are produced by the plant as a defence mechanism against fungal pathogens such as Botrytis cinerea (Waters et al., 1996) and are sought after because of their potential as biological control agents (Ferreira et al., 2004). Because they are resistant to proteolysis and to the low wine $\mathrm{pH}$, these pathogenesis-related proteins will be present after winemaking and can cause haze and sediment formation in wines (Ferreira et al., 2002). The haze-forming wine proteins are apparently similar in wines vinified from different grape varieties. Protein insolubility is not determined by the protein molecules themselves, but depends on non-protein factors such as the presence of polysaccharides, sulphate and the wine $\mathrm{pH}$ (Mesquita et al., 2001; Pocock et al., 2007).

Wine stability has been improved by wine lees due to the addition of yeast mannoproteins that play an important role in protein haze stabilization (Dupin et al., 2000a; 2000b). These compounds act as haze-protective colloids by carrying a negative charge in the wine $\mathrm{pH}$ range, establishing electrostatic and ionic interactions between unstable wine proteins. They have been identified as either high molecular weight $(420 \mathrm{kDa})$ or low molecular weight (32 kDa) polysaccharides (Waters et al., 1993; MoineLedoux and Dubourdieu, 1999). Protein adsorption onto metal oxide materials may stabilize white wine. Pachova et al. (2002) reported an almost complete removal of the 30-40 kDa protein fraction of Chardonnay for the first 70 bed volumes $(\mathrm{BV})$ of wine treated by powdered zirconium oxide, which agreed with a low turbidity difference $(0.66$ Nephelometric Turbidity Units (NTU)) of treated wine. Zirconium oxide showed a preferential protein removal of the 20-50 kDa and 50-70 kDa fractions from Chardonnay (Pashova et al., 2004a). However, selective removal of heat unstable proteins is very important, because the stable protein fractions have a positive influence on sensory wine properties, that is, confer structure and body to the wine and help to fix aromatic compounds.

Furthermore, phenolics are one of the most important wine compounds that affect wine stability and quality, since they contribute to organoleptic characteristics such as colour, astringency and bitterness, as well as its antioxidant capacity (Paixão et al., 2007). Hydrocinnamic acids (nonflavonoid phenolics) such as gallic acid, caffeic acid and caftaric acid, are the major phenolic compounds in white wine and are important in white wine colour. They are derived primarily from the pulp of the grape berry (Adams, 2006). Low molecular weight flavan-3-ols (catechins) from grape seeds are responsible for bitterness of wine and high molecular weight flavan-3-ols (catechins) from grape skins could be responsible for astringency in wines. The major flavan-3-ol monomers found in white wine include (+)-catechin and (-)-epicatechin. Much of the flavan-3-ol monomers originate from grape skin and seeds, where longer extraction times, higher temperatures and higher alcohol concentrations lead to an increase in flavan-3-ol monomer concentration (Kennedy et al., 2006). Proanthocyanidins or tannins are polymeric flavan3 -ols with a very wide range of molecular weight, found in grape skins and seeds (Adams, 2006). The formation of colloids involving tannins is of interest because colloids influence wine stability (Kennedy et al., 2006). Nevertheless, the amount of catechins, proanthocyanidins and tannic derivatives is quite low in white wines (Revilla and Ryan, 2000).

The objective of this work was to determine the influence of adsorption of proteins on the stability, and protein and phenolic composition of a Chardonnay wine.

\section{MATERIALS AND METHODS}

\section{Materials}

A Chardonnay wine from the Bio-Bio Valley, Chile (vintage 2005) was obtained after fermentation and prior to any stabilization treatment from a local winery. Prior to the stabilization at laboratory scale, suspended solids were separated from the wine by centrifugation at 9000 $g$ for 10 min (Damon IEC HN-SII, Damon, Needham, Massachussets, USA).

The following adsorbent was used in this study: SPTrisacryl-M (Sigma-Aldrich, St. Louis, Missouri, USA), a resin with a poly (N-tris [hydroxymethyl] methyl acrylamide) matrix, a cation exchange capacity between 190 and $250 \mu \mathrm{eq} \mathrm{mL}^{-1}$ and a particle size of $40-80 \mu \mathrm{m}$. Prior to the adsorption experiment, Trisacryl was washed in triplicate $(500 \mathrm{~mL}$ distilled water per $100 \mathrm{~g}$ resin), followed by filtration (Whatman No. 541).

\section{Stabilization treatment}

A continuous stabilization process was carried out at $19{ }^{\circ} \mathrm{C}$ in the Spectra/Chrom LC column (Spectrum, Houston, Texas, USA) $(\mathrm{H} \times \mathrm{ID}=0.5 \times 5 \mathrm{~cm})$ with adjustable plunger packed with $8.6 \mathrm{~g}$ of Trisacryl. Wine (1 L) was pumped downwards through the column using the Masterflex L/S peristaltic pump (Model 77250-62; Barnant, Barrington, Illinois, USA) at a flow rate of 1.4 $\mathrm{mL} \mathrm{min}^{-1}$. Then the adsorbent material was washed with 2 $\mathrm{L}$ of distilled water, and regenerated with $2 \mathrm{~L}$ of $1 \mathrm{M} \mathrm{HCl}$, followed by $11 \mathrm{~L}$ of distilled water.

\section{Protein analyses}

Total soluble protein concentration in the aliquots was evaluated by adding Coomassie brilliant blue reagent (Merck) and reading absorbance at $595 \mathrm{~nm}$ on the Sunny UV-7804C spectrophotometer (Sunny Optical Technology, Yuyao, Zhejiang, China) (Bradford, 1976). Bovine serum 
albumin (Calbiochem, San Diego, California, USA) was used as a standard to assess the protein concentration. All measurements were performed in duplicate.

The molecular weight profiles of several wine fractions were obtained by gel permeation chromatography. Gel filtration was carried out by HPLC, Hewlett Packard, Agilent 1100 series (Waldbronn, Germany), equipped with a UV detector at a wavelength of $220 \mathrm{~nm}$. The TSKGel G2000SW column (TosoHaas GmbH, Stuttgart, Germany) $(30 \times 0.75 \mathrm{~cm})$ with a TosoHaas TSK gel SW guard column (TosoHaas GmbH, Stuttgart, Germany) $(7.5 \times 0.75 \mathrm{~cm})$ and $100 \mu \mathrm{L}$ of injection volume was kept at $25^{\circ} \mathrm{C}$. A $0.2 \mathrm{M}$ phosphate buffer of $\mathrm{pH} 7.00$ containing $0.1 \mathrm{M}$ sodium chloride was used as eluent at constant flow rate of $1.0 \mathrm{~mL} \mathrm{~min}{ }^{-1}$. Bovine serum albumin (Sigma, molecular weight $[\mathrm{MW}] 67 \mathrm{kDa}$ ), chicken egg albumin (Sigma, MW $45 \mathrm{kDa}$ ) and lysozyme (Sigma, MW 14.5 $\mathrm{kDa}$ ) were used as MW standards. The analyses were performed in duplicate.

\section{Polyphenol analyses}

The Folin-Ciocalteu assay was used to measure total polyphenol content, using the Folin-Ciocalteu reagent (Merck) and reading absorbance at $750 \mathrm{~nm}$ with the Sunny UV-7804C spectrophotometer(Sunny Optical Technology, Yuyao, Zhejiang, China) (Singleton and Rossi, 1965). Concentrations were expressed as equivalents of gallic acid (Sigma-Aldrich). All measurements were performed in duplicate.

Phenolics were identified and quantified by HPLC (Hewlett Packard, Agilent 1100 series, Waldbronn, Germany) equipped with a diode array UV-vis detector. A Supelcosil LC-18 column (Sigma-Aldrich, St. Louis, Missouri, USA) $(25 \times 0.46 \mathrm{~cm})$, with a particle size of 5 $\mu \mathrm{m}$ and an injection volume of $100 \mu \mathrm{L}$ was kept at $40^{\circ} \mathrm{C}$. A constant flow rate of $1.5 \mathrm{~mL} \mathrm{~min}^{-1}$ was used with two solvents: solvent A, glacial acetic acid in water at $\mathrm{pH} 2.60$; solvent B, $20 \%$ solvent A mixed with $80 \%$ acetonitrile, following the elution program proposed by Betés-Saura $e t$ al. (1996). Adiode array UV-vis detector was used to choose the wavelength of maximum absorbance for each group of phenolics. The concentrations of the phenolic compounds identified were measured using external standard curves (Rózek et al., 2007). Gallic acid, trans-caftaric acid, transcoutaric acid, caffeic acid, coumaric acid, ferrulic acid, syringic acid, vanillic acid, tyrosol, rutin, quercetin, $(+)$ catechin, and (-)-epicatechin standards were purchased from Sigma-Aldrich (Steinheim, Germany). The analyses were performed in triplicate.

\section{Protein heat stability test}

The wine's protein stability was determined by heating samples in sealed bottles at $80{ }^{\circ} \mathrm{C}$ for $2 \mathrm{~h}$ in a water bath, followed by cooling at $4{ }^{\circ} \mathrm{C}$ for $2 \mathrm{~h}$. After allowing the samples to reach room temperature, their turbidity was measured with a Hach 2100P turbidimeter (Hach, Loveland, Colorado, USA) and expressed as Nephelometric Turbidity Units (NTU). Differences in wine turbidity before and after heat treatment is proportional to its protein instability (Pachova et al., 2002). The analyses were done in duplicate.

\section{RESULTS AND DISCUSSION}

\section{Protein removal}

Adsorption of wine proteins was done using the Trisacryl ion-exchange resin, where $\mathrm{C}$ is the total protein concentration at the outlet of the column, $\mathrm{C}_{0}$ is the total protein concentration at the inlet of the column and the bed volume $(\mathrm{BV})$ corresponds to the amount of treated wine $\left(\mathrm{mL}\right.$ wine $\mathrm{mL}^{-1}$ Trisacryl) (Figure 1). Initial protein content of Chardonnay was low $\left(13.4 \pm 0.3 \mathrm{mg} \mathrm{L}^{-1}\right)$ in our case. Protein removal by Trisacryl was about $40 \%$ during the first $65 \mathrm{BV}$ and decreased progressively until the end of the treatment (95 BV) with no protein removal at all (Figure 1). A more pronounced breakthrough of proteins started after eluting $65 \mathrm{BV}$ of wine, probably because the resin became saturated diminishing its protein adsorption capacity.

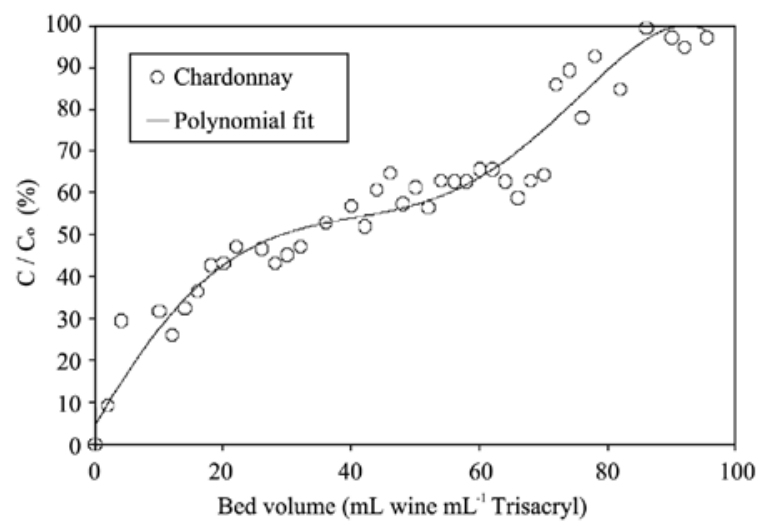

Figure 1. Breakthrough curve of wine proteins.

Protein instability of several wine fractions treated by Trisacryl has been measured by the difference in turbidity before and after heat treatment (Figure 2). The difference in turbidity of untreated wine was $27.0 \pm 6.0$ NTU. Thus continuous adsorption treatment of Chardonnay by Trisacryl was able to improve wine stability to a great extent. A more pronounced breakthrough of turbidity causing compounds has been observed after $65 \mathrm{BV}$ of wine elution (Figure 2), showing a striking agreement between protein removal and turbidity formation. Moreover, 
quantitative determination of turbidity by nephelometry (light scattering by suspended particles) agrees with qualitative assessments such as visual inspection to measure wine stability. However, several criteria for wine stability have been reported. Wines with turbidity values of 10 NTU or less will appear clear by eye (Weiss et al., 2001). Other visual inspections may include the examination of heat/chill treated wine for suspended particles using a penlight flashlight in a darkened room. Wines that were considered stable by this test had turbidity values between 0.5 and 3.6 NTU (Weiss et al., 2001). On the other hand, Moine-Ledoux and Dubourdieu (1999) considered wines to be stable if the difference in turbidity did not exceed 2 NTU. According to these criteria, our wine was only stable for the first $65 \mathrm{BV}, 8 \mathrm{BV}$ or $5 \mathrm{BV}$, respectively. However, protein adsorption and wine stability may be improved by increasing residence time (Salazar et al., 2006). This suggests that adsorption is a diffusion controlled process, where solute transport from the bulk fluid to the particle surface and solute transport inside the particle to the active adsorption sites should be rate-limiting.

Molecular weight profiles of several wine fractions show a complete removal of the 20-50 $\mathrm{kDa}$ protein fraction by Trisacryl during the first $18 \mathrm{BV}$ (Figure 3). After $62 \mathrm{BV}$, protein removal of the $20-50 \mathrm{kDa}$ fraction was less than $30 \%$. Protein instability of Chardonnay wines has been associated with the 20-50 kDa protein fraction, which agrees with other studies. Pashova et al. (2004b) reported that the 20 to $30 \mathrm{kDa}$ protein fraction was responsible for protein instability of Muscat wine. Salazar et al. (2007) showed that the 20-70 kDa fraction was the less heat stable protein fraction in Pinot Noir.

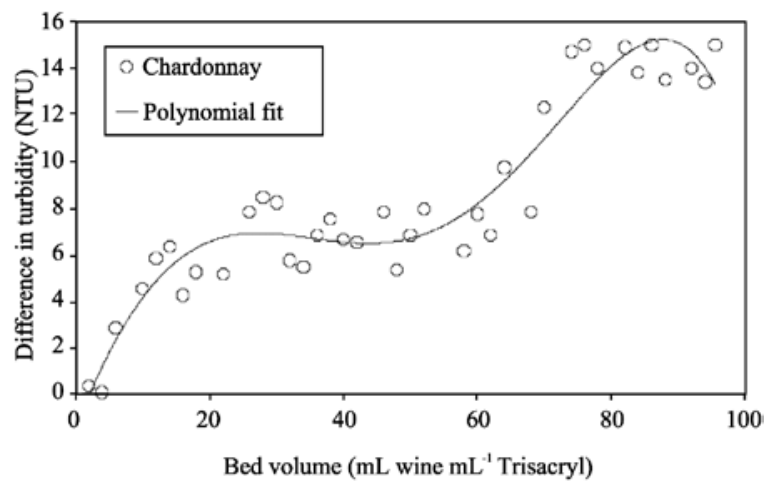

Figure 2. Turbidity behaviour of wine samples treated by Trisacryl.

\section{Polyphenol removal}

The concentrations of total phenol varied from 165 to $331 \mathrm{mg} \mathrm{L}^{-1}$ for California white wines (Frankel et al., 1995) and from 282 to $434 \mathrm{mg} \mathrm{L}^{-1}$ for Portuguese white wines (Paixão et al., 2007). In this study a total polyphenol concentration of $295.0 \pm 5.0 \mathrm{mg} \mathrm{L}^{-1}$ was found for Chardonnay wine. About $8 \%$ of the initial total polyphenol content was removed by Trisacryl (Figure 4). Thus Trisacryl showed higher selectivity for wine proteins than for wine phenolics due to the charged nature of protein molecules, having a net positive charge at the $\mathrm{pH}$ values found in wines (Ferreira et al., 2002).

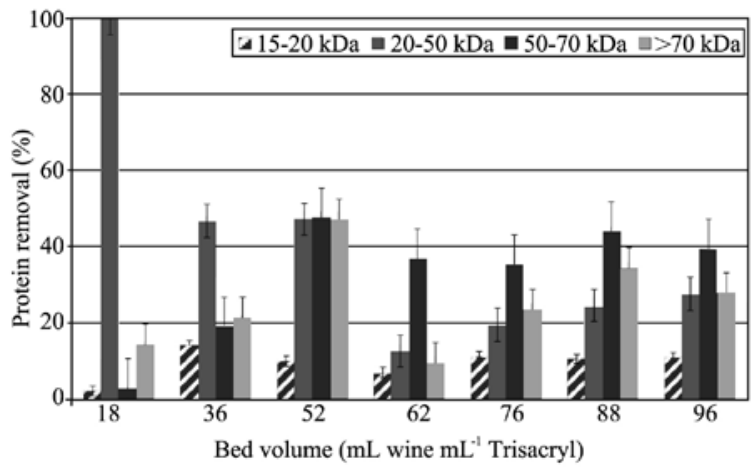

Figure 3. Protein removal from Chardonnay wine by Trisacryl according to molecular weight.

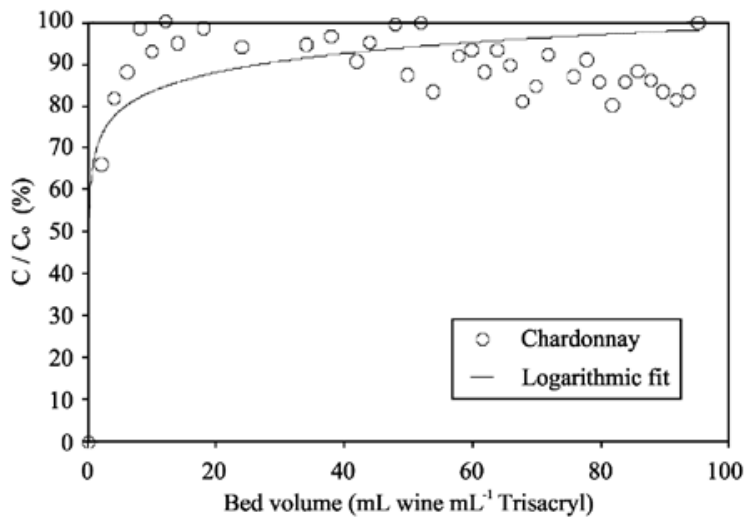

Figure 4. Breakthrough curve of wine polyphenols.

About $45 \%$ of the total phenolics identified and quantified by HPLC were flavonoids, such as (-)-epicatechin (Table 1). Remaining phenolics were identified as hydroxycinnamic acid (caffeic acid) and hydroxybenzoic acids (gallic, syringic and vanillic acids) and tyrosol, a degradation product of tyrosine (Table 1). Caffeic acid - a hydrolysis product caftaric acid - was the most stable phenolic compound during adsorption. (-)-Epicatechin was less stable. The hydroxybenzoic acids and tyrosol appear during processing.

\section{CONCLUSIONS}

The continuous treatment of a Chardonnay wine by a packed bed of Trisacryl ion-exchange resin improves 
Table 1. Phenolic profile of a Chardonnay wine treated by Trisacryl.

\begin{tabular}{cccccccc}
\hline $\begin{array}{c}\text { Bed volume } \\
\text { (BV) }\end{array}$ & Caffeic acid & (-)-Epicatechin & Gallic acid & Syringic acid & Vanillic acid & Tyrosol \\
\hline & & & & & & & \\
\cline { 6 - 7 } & & & & & & & \\
& $5.43 \pm 0.08$ & $4.46 \pm 0.27$ & nd & nd & nd & nd \\
18 & $4.80 \pm 0.12$ & $1.06 \pm 0.00$ & nd & nd & nd & nd \\
36 & $5.06 \pm 0.07$ & $2.72 \pm 0.12$ & nd & nd & nd & nd \\
52 & $5.24 \pm 0.07$ & $3.87 \pm 0.25$ & nd & $0.38 \pm 0.00$ & $0.88 \pm 0.00$ & nd \\
62 & $5.39 \pm 0.06$ & $3.86 \pm 0.53$ & $4.99 \pm 0.41$ & $0.41 \pm 0.00$ & nd & $3.41 \pm 0.00$ \\
76 & $5.12 \pm 0.07$ & $3.76 \pm 0.27$ & $2.14 \pm 0.00$ & nd & nd & nd \\
88 & $5.17 \pm 0.07$ & $2.72 \pm 0.03$ & nd & $0.50 \pm 0.32$ & nd & nd \\
96 & $5.08 \pm 0.08$ & $3.55 \pm 0.68$ & nd & nd & nd & nd \\
\hline
\end{tabular}

nd: not detected. Data are average of three replicates. BV is expressed as $\mathrm{mL}$ wine $\mathrm{mL}^{-1}$ Trisacryl.

its stability. The instability of Chardonnay depends upon the protein content of wine; in particular, the $20-50 \mathrm{kDa}$ protein fraction seems to be related to wine instability. Selective adsorption of this fraction onto the resin improves wine stability. No influence of phenolics on white wine stabilization can be assessed. Caffeic acid and (-)-epicatechin represent the major percentage in the total amount of identified phenols.

\section{ACKNOWLEDGEMENTS}

Authors acknowledge the financial support from the Universidad de Concepción, DIUC project No. 205.134.003-1.0, and the Agencia Española de Cooperación Internacional, AECI project No. A/4726/06, as well as Viñedos de Canata, Cabrero, for providing the Chardonnay wine.

\section{RESUMEN}

Estabilización en continuo de Chardonnay con resina de intercambio iónico: Efecto en los perfiles proteicos y fenólicos del vino. Proteínas inestables pueden reaccionar con polifenoles, formando turbidez y precipitación en vinos blancos. Por ende, la adsorción de estas proteínas de vino es una etapa esencial en la producción de vinos blancos. El objetivo de este estudio fue determinar la influencia de la adsorción de estas proteínas en la estabilidad y la composición proteica y fenólica de un vino Chardonnay. En este trabajo, la estabilización proteica de vino Chardonnay se realizó mediante adsorción en continuo, utilizando un lecho empaquetado con adsorbente de SP-Trisacryl-M (SigmaAldrich). Un quiebre más pronunciado de proteínas y componentes causantes de turbidez se encontró después de pasar un volumen de vino equivalente a 65 lechos de volumen de Trisacryl a través de la resina. Una mayor retención de la fracción proteica de 20-50 kDa durante los primeros 62 lechos de volumen de vino tratado se relacionó con una mayor estabilidad del vino tratado mediante Trisacryl. La remoción de los fenoles mediante Trisacryl fue baja. El ácido cafeico y (-)-epicatequina fueron los principales compuestos fenólicos detectados mediante cromatografía líquida de alta eficiencia (HPLC). Chardonnay, un vino de bajo contenido proteico, mejoró su estabilidad después del tratamiento con Trisacryl debido a la adsorción de la fracción proteica de 20-50 kDa.

Palabras clave: adsorción, Trisacryl, Vitis vinifera, purificación, Chile.

\section{LITERATURE CITED}

Adams, D.O. 2006. Phenolics and ripening in grape berries. Am. J. Enol. Vitic. 57:249-256.

Betés-Saura, C., C. Andrés-Lacueva, and R.M. LamuelaRaventós. 1996. Phenolics in white free run juices and wines from Penedès by high-performance liquid chromatography: changes during vinification. J. Agric. Food Chem. 44:3040-3046.

Bradford, M.M. 1976. A rapid and sensitive method for the quantification of microgram quantities of protein utilizing the principle of protein-dye binding. Anal. Biochem. 72:248-254.

De Bruijn, J., C. Loyola, A. Flores, F. Hevia, P. Melín, and I. Serra. 2008. Protein stabilization of Chardonnay wine using trisacryl and bentonite: a comparative study. Int. J. Food Sci. Technol. doi: 10.1111/j.13652621.2008.01720.x (In press). 
Dupin, I.V.S., V.J. Stockdale, P.J. Williams, G.P. Jones, A.J. Markides, and E.J. Waters. 2000a. Saccharomyces cerevisiae mannoproteins that protect wine from protein haze: evaluation and extraction methods and immunolocalization. J. Agric. Food Chem. 48:10861095.

Dupin, I.V.S., B.M. McKinnon, C. Ryan, M. Boulay, A.J. Markides, G.P. Jones, et al. 2000b. Saccharomyces cerevisiae mannoproteins that protect wine from protein haze: their release during fermentation and lees contact and a proposal for their mechanism of action. J. Agric. Food Chem. 48:3098-3105.

Ferreira, R.B., S. Monteiro, M.A. Piçarra-Perreira, and A.R. Teixeira. 2004. Engineering grapevine for increased resistance to fungal pathogens without compromising wine stability. Trends Biotechnol. 22:168-173.

Ferreira, R.B., M.A. Piçarra-Perreira, S. Monteiro, V.B. Loureiro, and A.R. Teixeira. 2002. The wine proteins. Trends Food Sci. Technol. 12:230-239.

Frankel, E.N., A.L. Waterhouse, and P.L. Teissedre. 1995. Principle phenolic phytochemicals in selected California wines and their antioxidant activity in inhibiting oxidation of human low-density lipoproteins. J. Agric. Food Chem. 43:890-894.

Kennedy, J.A., C. Saucier, and Y. Glories. 2006. Grape and wine phenolics: history and perspective. Am. J. Enol. Vitic. 57:239-248.

Mesquita, P.R., M.A. Piçarra-Perreira, S. Monteiro, V.B. Loureiro, A.R. Teixeira, and R.B. Ferreira. 2001. Effect of wine composition on protein stability. Am. J. Enol. Vitic. 52:324-330.

Moine-Ledoux, V., and D. Dubourdieu, 1999. An invertase fragment responsible for improving the protein stability of dry white wines. J. Sci. Food Agric. 79:537-543.

Pachova, V., M. Ferrando, C. Güell, and F. López. 2002. Protein adsorption onto metal oxide materials in white wine model systems. J. Food Sci. 67:2118-2121.

Paixão, N., R. Perestrelo, J.C. Marques, and J.S. Câmara. 2007. Relationship between antioxidant capacity and total phenolic content of red, rosé and white wines. Food Chem. 105:204-214.

Pashova, V., C. Güell, and F. López. 2004a. White wine continuous protein stabilization by packed column. J. Agric. Food Chem. 52:1558-1563.

Pashova, V., C. Güell, E. Pueyo, M. López-Barajas, M.C. Polo, and F. López. 2004b. White wine protein stabilization by a continuous process using a packed column. Am. J. Enol. Vitic. 55:195-198.
Pocock, K.F., G.M. Alexander, Y. Hayasaka, P.R. Jones, and E.J. Waters, 2007. Sulfate - a candidate for the missing essential factor that is required for the formation of protein haze in white wine. J. Agric. Food Chem. 55:1799-1807.

Revilla, E., and J.M. Ryan, 2000. Analysis of several phenolic compounds with potential antioxidant properties in grape extracts and wines by highperformance liquid chromatography-photodiode array detection without sample preparation. J. Chromatogr. A 881:461-469.

Rózek, A., I. Achaerandio, M.P. Almajano, C. Güell, F. López, and M. Ferrando. 2007. Solid foodstuff supplemented with phenolics from grape: antioxidant properties and correlation with phenolic profiles. J. Agric. Food Chem. 55:5147-5155.

Salazar, F.N., I. Achaerandio, M.A. Labbé, C. Güell, and F. López. 2006. Comparative study of protein stabilization in white wine using zirconia and bentonite: physicochemical and wine sensory analysis. J. Agric. Food Chem. 54:9955-9958.

Salazar, F.N., J.P.F. de Bruijn, L. Seminario, C. Güell, and F. López. 2007. Improvement of wine crossflow microfiltration by a new hybrid process. J. Food Eng. 79:1329-1336.

Siebert, K.J. 1999. Effects of protein - polyphenol interactions on beverage haze, stabilization, and analysis. J. Agric. Food Chem. 47:353-362.

Singleton, V.L., and J.A. Rossi. 1965. Colorimetry of total phenolics with phosphomolybdic-phosphotungstic acid reagents. Am. J. Enol. Vitic. 16:144-158.

Tattersall, D.B., R. Heeswijck, and P.B. Hoj. 1997. Identification and characterization of a fruit-specific, thaumatin-like protein that accumulates at very high levels in conjunction with the onset of sugar accumulation and berry softening in grapes. Plant Physiol. 114:759-769.

Waters, E.J., N.J. Shirley, and P.J. Williams. 1996. Nuisance proteins of wine are grape pathogenesisrelated proteins. J. Agric. Food Chem. 44:3-5.

Waters, E.J., W. Wallace, M.E. Tate, and P.J. Williams. 1993. Isolation and partial characterization of a natural haze protective factor from wine. J. Agric. Food Chem. 41:724-730.

Waters, E.J., W. Wallace, and P.J. Williams. 1991. Heat haze characteristics of fractionated wine proteins. Am. J. Enol. Vitic. 42:123-127.

Weiss, K.C., L.W. Lange, and L.F. Bisson. 2001. Smallscale fining trials: effect of method of addition on efficiency of bentonite fining. Am. J. Enol. Vitic. 52:275-279. 